\title{
Gingival condition of patient with obesity
}

\author{
Atikah Sabrina Alyani*, Sri Wendari Hartono*, Dede Hadidjah* \\ *Department of Periodontics Faculty of Dentistry Universitas Padjadjaran
}

\section{ABSTRACT}

The prevalence of obesity has increased drastically in most developed countries. Many studies showed that obesity associated with oral diseases, especially periodontal disease. A recent study showed the relation between WC and periodontal disease counted by gingival index (GI). However, studies regarding the mechanism of the relationship between obesity and periodontal disease are still quite a few, whereas many studies conducted suggested that obesity was a medical problem. The study was aimed to know and assess the gingival condition of obese people who visited the Dental Polyclinic of Hasan Sadikin Hospital. The type of this study was descriptive with the survey technique. A total of 54 people consisted of 35 female and 19 male patients with the age range of 20-49 years old, and not using any dental prosthesis or orthodontic appliance. This study was using a questionnaire and clinical examination to assess the condition of the gingival using the Löe and Silness Gingival index (GI). Examination of obesity conducted by measuring the waist circumference with criteria from WHO. The average value of the gingival index was 1.22. Meanwhile, the average value of the waist circumference (WC) was $95.89 \mathrm{~cm}$ and 107.74 $\mathrm{cm}$ consecutively for female and male. The majority of obese patients suffered moderate gingivitis.

Keywords: Gingival Index, obesity, obese people, Waist Circumference (WC)

\section{INTRODUCTION}

Overweight is a condition where the balance between body weight and body height exceeds the usual standard. Meanwhile, obesity is a condition of excessive fat resides in a body, whether in the whole body or localized in particular parts. ${ }^{2}$

Obesity is a disruption in metabolism and nutrition with complex multi-factors developed between genotype and environment interaction. Other factors such as lifestyle, overweight, sugar consumption, and a decrease in physical activity due to the nature of occupations and developing modern transportation, also have parts in the increase of obesity's prevalence. Obesity was known as the prime factor of systemic diseases such as hypertension, type II diabetes, high cholesterol level, coronary disease, and others. ${ }^{3}$

A new study discovered that the nutrition status was an important factor in periodontal patient and showed that obesity could be a potential risk factor for periodontal disease. Obesity increases the host's susceptibility towards periodontal disease due to the change of immunity and host's inflammation. Relation between obesity and periodontal disease was more prominent in the young adults than elderly because the metabolism shifts occurred in the later life. ${ }^{3}$ 
Estimation of the overweight and obesity prevalence in Indonesia amongst 210 million Indonesian citizens in 2000 was reached 76.7 million (17.5\%) and 9.8 million $\left(4.7 \%\right.$ ) consecutively. ${ }^{4}$ Based on those data, it was concluded that overweight and obesity in Indonesia was a huge problem that needs serious handling. ${ }^{5}$

Majority of previous studies were using body index mass (BMI) as an overweight indicator. $\mathrm{BMI}$ is a ratio between body weight (kilogram) and body height (meter). New studies improved obesity indicator with the calculation of waist circumference (WC) and waist-hip ratio (WHR). ${ }^{3}$

A recent study showed the relation between WC and periodontal disease counted by the gingival index $(\mathrm{Gl}){ }^{6}{ }^{6}$ Research on Japanese citizens also discovered the relationship between obesity and periodontal disease. This research used BMI and WC as the marker, resulted in a significant relationship between obesity and periodontal disease, particularly in young adults, but not for adults and elderly. ${ }^{8}$

Reports about the mechanism between obesity and periodontal diseases are still quite a few. On the contrary, many reports showed obesity as a medical problem. Based on descriptions above, this study was aimed to know and assess the gingival condition of obese people who visited the Dental Polyclinic of Hasan Sadikin Hospital.

\section{METHODS}

This research was a descriptive research with survey technique. Research population was obesity patients that attended Dental Polyclinic of Hasan Sadikin Hospital in October 2011. As much as 54 obesity patients with criteria such as follows: male and female; the age range of 18 49 years old; waist circumference (WC) more than $102 \mathrm{~cm}$ (male) and more than $88 \mathrm{~cm}$ (female) ${ }^{1}$; and not using any dental prosthesis or orthodontic appliances. Tools and materials used were the mouth mirror, probe, excavator, tweezer, cotton, alcohol $70 \%$, disposable glass, handscoon, mask, measuring tape, exam forms, informed consent.

\section{RESULTS}

The result of the examination of the gingival conditions in obese patients attended the Dental
Table 1. Respondents characteristics

\begin{tabular}{lccc}
\hline & $\mathrm{N}$ & $\begin{array}{c}\text { Average WC* } \\
(\mathrm{cm})\end{array}$ & $\%$ \\
\hline Age (year) & 16 & 99.19 & 29.6 \\
\hline $18-28$ & 20 & 98.90 & 37 \\
$29-39$ & 18 & 102.11 & 33.3 \\
$40-50$ & & & \\
\hline Gender & 35 & 95.89 & $64.8 \%$ \\
\hline Female & 19 & 107.74 & $35.2 \%$ \\
Men & &
\end{tabular}

Table 2. Average value of the Gingival Index (GI) and Waist Circumference (WC) in obese patients based on the age and gender

\begin{tabular}{lcccc}
\hline Indicator & $\mathrm{n}$ & $\begin{array}{c}\text { Waist circum- } \\
\text { ference }(\mathbf{c m})\end{array}$ & $\begin{array}{c}\text { Gingival } \\
\text { index }\end{array}$ & $\begin{array}{c}\text { Gingivitis } \\
\text { Category }\end{array}$ \\
\hline Age (year) & & & & \\
\hline $18-28$ & 16 & 99.19 & 0.87 & Low \\
$29-39$ & 20 & 98.90 & 1.28 & Medium \\
$40-50$ & 18 & 102.11 & 1.50 & Medium \\
\hline Gender & & & & \\
\hline Female & 35 & 95.89 & 1.10 & Medium \\
Male & 19 & 107.74 & 1.50 & Medium \\
\hline \multicolumn{1}{c}{ Total } & $\mathbf{5 4}$ & $\mathbf{1 0 1 . 8 2}$ & 1.30 & Medium \\
\hline
\end{tabular}

Table 3. Percentage of gingivitis severity in obese patients

\begin{tabular}{lcc}
\hline Gingivitis severity & $\mathbf{n}$ & $\%$ \\
\hline Normal & 0 & 0 \\
Mild & 21 & 38.9 \\
Moderate & 30 & 55.6 \\
Severe & 3 & 5.6 \\
\hline
\end{tabular}

Polyclinic of Hasan Sadikin Hospital in October 2011 were shown in Table 1, 2, and Table 3 below.

\section{DISCUSSION}

This research result showed that every obesity patients suffered gingivitis from mild to moderate category. This result was consistent with a study conducted by Khader in 2009 that showed people with obesity tend to have an escalation in periodontal disease's prevalence, severity, and extension. ${ }^{3}$ Furthermore, result of studies conducted by Amin in 2008 showed a significant correlation between subjects with high waist circumference and high gingival index compared to subjects with normal waist circumference. ${ }^{9}$ 
The mechanism of obesity as a risk factor for periodontal disease is TNF-a (necrotic tumor alpha-factor) synthesized by fat tissue in obesity patient. TNF- $\alpha$ is one of proinflammation cytokine that takes part in periodontal disease by its activity, such as triggering proliferation, differentiation, and osteoclast activity in bone resorption, inducing proteinase production in mesenchyme that breaks down connective tissue. ${ }^{10}$ TNF- $a$ affects endotoxin secretion that increases injury to various organs, including periodontal tissue. TNF-a could increase the periodontal degradation process resulting in periodontal disease. ${ }^{11}$

Gingivitis severity level in obese patients tends to increase along with age. This was consistent with research conducted by Saito in 2007 that showed that obesity was the low-level systemic inflammation type disease. ${ }^{11}$ TNF- $\alpha$ from adipose tissue in adult obesity patient could resulting in periodontal tissue damage in the later age, even though the patient did not suffer periodontal disease in the early life. However, this result was contrary to the study conducted by AlZahrani in 2003 that showed a relationship between obesity and periodontal disease could happen in young adults, but not in adults and elderly. ${ }^{8}$

Other than related to periodontal disease, obesity, particularly in the upper body, could increase the risks of disease in adults such as the type II diabetes, cardiovascular disease, stroke, and hypertension. This condition correlates to the visceral fat accumulation producing TNF-a resulting in the insulin resistance. Visceral fat or intra abdomen fat is the fat surrounding internal organs. ${ }^{11}$ Maintaining normal body weight, balanced diet, and physical activity was needed to be done to decrease periodontal disease caused by obesity. ${ }^{3}$

The periodontal disease could be affected by many factors other than obesity such as oral hygiene. Oral hygiene determined by debris, plaque, calculus, alba materials and stain on the tooth surface. ${ }^{12}$ Research conducted by Amin in 2008 showed that the bad oral hygiene could trigger systemic inflammation, including periodontal disease. ${ }^{9}$

Sufficient frequency, appropriate time, and proper method of toothbrushing required for better oral hygiene. Effective toothbrushing controls plaque but not calculus. Therefore, a routine dental check-up by professional dentists is also required. From the questionnaires results in this research showed that respondents were aware of the right toothbrushing frequency with proper toothbrushing technique, but still unaware of the appropriate time. Also, the majority of respondents did not perform a routine dental check-up and visit dentists only when there was any oral problem.

The periodontal disease could be prevented in the early phase with simple treatment. Developing disease increase the damage in supportive tissue and required more complex therapy. ${ }^{13}$ Gingivitis could be recovered after the plaque and calculus removal, with a good oral health care. ${ }^{14}$ Therefore, to obtain an optimal oral health, besides the individual oral health care, treatment by professional dentists are also required.

\section{CONCLUSION}

The majority of obese patients attended Dental Polyclinic of Hasan Sadikin Hospital suffered moderate gingivitis.

\section{REFERENCES}

1. World Health Organization. Obesity: preventing and managing the global epidemic. Report of a WHO Consultation (WHO Technical Report Series 894). Geneva: World Health Organization; 2000.

2. Ganong WF. Buku Ajar Fisiologi Kedokteran. 20th ed. Jakarta: EGC; 2002.

3. Khader YS, Bawadi HA, Haroun TF, Alomari M, Tayyem RF. The Association between Periodontal Disease and Obesity Among Adults in Jordan. J Clin Periodontol. 2009 Jan;36(1):18-24.

4. Directorate of Public Nutrition. Perkiraan Prevalensi Overweight dan Obesitas di Indonesia. Jakarta: Ministry of Health of Republic of Indonesia; 1997.

5. Dokter Sehat [homepage on internet]. Jakarta: Pamela RD. 2011. Overweight dan Obesitas Sebagai Suatu Resiko Penyakit Degeneratif. [cited 2011 October 9]; [about 4 screens]. Available from: http://doktersehat. com/overweight-dan-obesitas-sebagai-suaturesiko-penyakit-degeneratif/ 
6. Saito T, Shimazaki Y, Sakamoto M. Obesity and Periodontitis. New Eng J Med. 1998;339(7):4823.

7. Amin HES. Relationship between overall and abdominal obesity and periodontal disease among young adults/Rapport entre obésité générale, obésité abdominale et parodontopathies chez les jeunes adultes. East Meditteran Health J. 2010 Apr;16(4):42933.

8. Al-Zahrani MS, Bissada NF, Borawskit EA. Obesity and Periodontal Disease in Young, Middle-age, and Older Adults. J Periodontol. 2003 May;74(5):610-5.
9. Daliemunthe SH. Obesitas Sebagai Faktor Resiko Penyakit Periodontal. Dentika Dent J. 2006;11(2):184-7.

10. Saito T, Shimazaki Y. Metabolic Disorder Related to Obesity and Periodontal Disease. Periodontol 2000. 2007;43:254-66.

11. Hoag PM, Pawlak EA. Essential of Periodontics. 4th ed. St. Louis: C.V. Mosby Co.; 1990. p. 1-61.

12. Forrest JO. Pencegahan Penyakit Mulut. Jakarta: Hipokrates; 1989.

13. Wilson TG, Kornman KS. Fundamentals of Periodontics. 1st ed. Chicago: Quintessence Publishing Co. Inc.; 1996. p. 295-300, 328-43. 